\title{
La relación alumno-docente en el cine español en torno a la guerra civil y la dictadura: de Valentina a Vivir es fácil con los ojos cerrados
}

\section{Resumen}

La relación alumno-docente protagoniza numerosas películas que retratan la España pre- o post-guerra civil: Valentina (Antonio José Betancor, 1982), La lengua de las mariposas (José Luis Cuerda, 1999), El espinazo del diablo (Guillermo del Toro, 2001), Eres mi héroe (Antonio Cuadri, 2002), Vivir es fácil con los ojos cerrados (David Trueba, 2013), y la adaptación del ensayo de Andrés Sopeña Monsalve, El florido pensil (Juan José Porto, 2002); también aparece, si bien enfoca al grupo de alumnos en su conjunto y diversidad, en Las largas vacaciones del 36 (Jaime Camino, 1976). Quizás la explicación se encuentre en las declaraciones del italiano Luigi Comencini, cineasta de la niñez, quien veía la infancia como el único momento de libertad del individuo, destinado a ser dramáticamente reprimido por la educación (tanto escolar como familiar). Sin embargo, la mayor parte de las figuras citadas son más bien emancipadoras, motores del desarrollo individual del alumno, y no encarnaciones del autoritarismo. La razón de la idealización de dicha relación docente-alumno podría radicar tanto en un imaginario nostálgico de la ILE como en el homenaje a una figura (el docente) que fue a menudo objeto de la represión dictatorial. No obstante y extrañamente, escasos son los ejemplos de la relación maestra-alumna, al menos como núcleo argumental, y las pocas figuras de profesoras que ofrece el cine español sobre este período se corresponden más bien con estereotipos temibles o eróticos.

Palabras-claves: cine, alumno, docente, guerra civil española, dictadura franquista
Bénédicte Brémard

Université de Bourgogne

Franche-Comté - França

benedicte.bremard@gmail.com

\section{Para citar este artigo:}

BRÉMARD, Bénédicte. La relación alumno-docente en el cine español en torno a la guerra civil y la dictadura: de Valentina a Vivir es fácil con los ojos cerrados. Revista Linhas. Florianópolis, v. 21, n. 47, p. 73-102, set./dez. 2020. 


\section{Relationship between pupil and teacher in Spanish cinema over the civil war and Francoist dictatorship: from Valentina to Living is easy with eyes closed}

\begin{abstract}
The relationship between pupil and teacher is depicted in numerous films that portray pre- or post-civil war Spain: Valentina (Antonio José Betancor, 1982), La lengua de las mariposas (José Luis Cuerda, 1999), El espinazo del diablo (Guillermo del Toro, 2001), Eres mi héroe (Antonio Cuadri, 2002), Vivir es fácil con los ojos cerrados (David Trueba, 2013), and the adaptation of Andrés Sopeña Monsalve's essay El florido pensil (Juan José Porto, 2002); it also appears, although it focuses on the group of pupils as a whole and diverse, in Las largas vacaciones del 36 (Jaime Camino, 1976). Perhaps the explanation can be found in the statements of Italian Luigi Comencini, a filmmaker specialized in childhood, who saw it as the only moment of freedom of the individual, destined to be dramatically suppressed by education (both at school and within the family). However, most of the characters cited are rather emancipatory, driving forces of the individual development of the pupil, and not incarnations of authoritarianism. The reason for the idealization of such a teacher-student relationship could lie both in a nostalgic imaginative universe of the ILE (The Free Institution of Education) and in the tribute to a character (the teacher) who had often been the subject of dictatorial repression. However, strangely, there are very few examples of the female teacher-female pupil relationship at least as the chore of a plot, and the few characters of female teachers offered by Spanish cinema over this period correspond rather to fearsome or erotic stereotypes.
\end{abstract}

Keywords: Film. Pupil. Teacher. Spanish civil war. Francoist dictatorship.
A relação aluno-professor no cinema espanhol em torno da Guerra Civil e da ditadura: de Valentina a Viver é fácil com os olhos fechados

\section{Resumo}

A relação aluno-professor protagoniza inúmeros filmes que retratam a Espanha pré ou pós-guerra civil: Valentina (Antonio José Betancor, 1982), A Língua das Mariposas (José Luis Cuerda, 1999), A Espinha do Diabo (Guillermo del Toro , 2001), Você é meu herói (Antonio Cuadri, 2002), Viver é fácil com os olhos fechados (David Trueba, 2013), e a adaptação do ensaio de Andrés Sopeña Monsalve, O florido pensil (Juan José Porto, 2002); também aparece, embora se concentre no grupo de alunos como um todo e na diversidade, em As longas férias de 36 (Jaime Camino, 1976). Talvez a explicação possa ser encontrada nas declarações do italiano Luigi Comencini, um cineasta de la infãncia, que via a infãncia como o único momento de liberdade do indivíduo, destinado a ser dramaticamente reprimido pela educação (tanto na escola quanto na família). No entanto, a maioria das figuras citadas são bastante emancipadas, motores do desenvolvimento individual do aluno, e não encarnações do autoritarismo. $O$ motivo da idealização dessa relação professoraluno poderia residir tanto em um imaginário nostálgico da ILE quanto na homenagem a uma figura (o professor) muitas vezes objeto de repressão ditatorial. No entanto, estranhamente, há poucos exemplos da relação professor-aluno, pelo menos como núcleo da trama, e as poucas figuras de professores que o cinema espanhol oferece sobre esse período correspondem ao estereótipos temíveis ou eróticos.

Palavras-chave: Cinema. Estudante. Professor. Guerra Civil Espanhola. Ditadura de Franco. 
Para nosotros, las voces de la infancia y juventud eran una defensa y una ayuda. Con sus recuerdos, íbamos aguantando la angustia que se siente cuando te limitan el espacio, y ni tus pies pueden ir donde irían, ni tus manos hacer lo que quisieran. (Valentina)

La infancia me parece ser el único momento de gran libertad para un individuo. El proceso por el cual la educación, escolar como familiar, tiende a ahogar dicha libertad es dramático. (VALLET, p. 107, traducción nuestra)

La reflexión de Luigi Comencini (1916-2007), renombrado cineasta de la infancia (dirigió entre muchas otras películas Heidi, Incompreso, Le avventure di Pinocchio, Un ragazzo di Calabria, Marcellino pane e vino...) nos invita a considerar la infancia como paréntesis de libertad que la educación escolar o familiar viene a interrumpir. El niño y el docente serían, por lo tanto, antagonistas llamados a oponerse en un proceso de tensión entre la sed de libertad y juego de uno y el propósito educativo del otro que tiende a reducir dicha libertad en el aprendizaje del saber pero sobre todo de las normas sociales. Si esta declaración parece inspirada en el pensamiento romántico que heredó de Rousseau la idealización de la infancia supuestamente pura e inocente, es de notar que el cine español ofrece numerosos ejemplos de puesta en escena de este esquema en el marco de películas que retratan la España pre- o post-guerra civil: Valentina (Antonio José Betancor, 1980), La lengua de las mariposas (José Luis Cuerda, 1999), El espinazo del diablo (Guillermo del Toro, 2001), Eres mi héroe (Antonio Cuadri, 2002), Vivir es fácil con los ojos cerrados (David Trueba, 2013), y evidentemente la adaptación del ensayo de Andrés Sopeña Monsalve, El florido pensil (Juan José Porto, 2002). También aparece la relación maestro-docente, si bien en este caso enfoca al grupo de alumnos en su conjunto y diversidad, en Las largas vacaciones del 36 (Jaime Camino, 1976). Sin embargo, la mayor parte de las figuras citadas aparecen más bien como figuras emancipadoras, motores del desarrollo individual del alumno, y no como estereotipos del autoritarismo. La razón de la idealización de dicha relación docentealumno podría radicar tanto en un imaginario nostálgico de la ILE como en el homenaje a una figura (el docente) que fue a menudo objeto de la represión dictatorial. No obstante y extrañamente, uno de los escasos ejemplos que nos ofrece el cine español de la relación 
maestra-alumna (pero desde un contexto desterritorializado) adopta la perspectiva del terror: se trata de La residencia (Narciso Ibáñez Serrador, 1969).

¿Por qué el cine español de la democracia que vuelve sobre la dictadura y sus orígenes toma el camino opuesto al estereotipo vigente en el imaginario colectivo desde el romanticismo, y efectivo en el cine de Comencini -que también conoció un régimen fascista? ¿Cómo y hasta qué punto se manifiesta una relación de complicidad o incluso de igual a igual entre el alumno y el docente -sin renunciar a la puesta en escena de la función educativa? ¿Por qué esta misma relación está presentada de forma opuesta en el caso femenino? Son los cuestionamientos que trataremos de abordar a través de este breve intento de tipología de la relación alumno-docente que se esboza en las películas citadas. Este análisis nos llevará a considerar primero la figura del maestro como un (anti)retrato, que se elabora a contracorriente de los estereotipos no sólo para el espectador sino para el mismo personaje del alumno; en segundo lugar, analizaremos las secuencias en que se presenta más como un amigo que como un profesor; en un tercer momento, podremos comprobar sin embargo que sigue vigente su rol educativo, si bien más como el de un iniciador que como un docente; y finalmente, nos preguntaremos si esta tipología se corresponde, o no, con las escasas apariciones de educadoras.

Siendo bastante importante el corpus, no podremos dedicarles el mismo espacio a todas las películas. Nos ha parecido interesante tomar como punto de partida la película Valentina, porque representa la infancia de la generación que se haría adulta con la guerra civil, y sin embargo, inaugura un imaginario alrededor de la relación alumno-docente que se repite en las películas que retratan las décadas siguientes con las cuales iremos comparándola. No obstante, en nuestro estudio, tendremos que tomar en cuenta las diferencias de contextos representados: Valentina (adaptación de la primera parte del relato autoficticio de Ramón J. Sender, Crónica del alba) narra una infancia a principios del siglo XX', si bien el marco creado por el anuncio de la muerte del protagonista en el campo de concentración de Argelès tras la guerra civil permite leerla como prolepsis del

\footnotetext{
${ }^{1}$ Una inscripción en la pantalla la sitúa precisamente en 1911.
} 
enfrentamiento de las dos Españas y de su destino en dicho conflicto ${ }^{2}$. La lengua de las mariposas (adaptación que sintetiza varias novelas cortas de la recopilación ¿Qué me quieres, amor? de Manuel Rivas) se desarrolla en los últimos días de la II República. Los argumentos de Las largas vacaciones del 36 y El espinazo del diablo se ubican durante la guerra civil. El florido pensil (adaptación del libro de memorias de Andrés Sopeña Monsalve) se desarrolla durante los años 1950, mientras que Vivir es fácil con los ojos cerrados y Eres mi héroe en los años 1966 y 1975. Finalmente, el contexto de La residencia es -sin duda voluntariamente- desplazado a la Provenza francesa de finales del s. XIX-principios del s. XX para no dejar lugar a comparaciones directas con el de su rodaje en la España del tardofranquismo, cuyo ambiente queda sin embargo perfectamente reflejado mediante el universo cerrado del colegio de chicas dirigido por una mujer autoritaria hasta la crueldad. Evidentemente, la visión de la relación alumno-docente y de los períodos que rodean la guerra civil y la dictadura tampoco es idéntica entre 1976, fecha del estreno de Las largas vacaciones del 36, y 2013, cuando se estrena Vivir es fácil con los ojos cerrados. Como explica el historiador Marc Ferro, el cine tiene la capacidad de proponer versiones alternativas de la Historia:

[El cine] ayuda a entender lo que pudo ser el pasado, dado que la historia es tanto la relación entre pasado y presente como lo que, en el presente, es la herencia del pasado [... ]. Además, ¿no es a menudo la película [... la la que, más que la historia de los historiadores, desvela los lapsus y los nodichos de una sociedad, revela su imaginario y la repercusión de la historia en cada uno de nosotros ? (FERRO, 2003, p. 162-163, traducción nuestra)

\section{El maestro no pega}

El primer aspecto que nos llama la atención es la construcción de la figura del docente al revés de los estereotipos. En Valentina, el maestro del joven Pepe (Jorge Sanz) es el cura del pueblo, Mosén Joaquín (Anthony Quinn). La elección del actor mejicano

\footnotetext{
${ }^{2}$ Como declaró el autor: "La vida de la infancia en una aldea española de 1909-1910 nos parece hoy el paraíso perdido", Carta a Joaquín Maurín, 9/03/1972 (CAUDET). Ramón Oteo Sans habla de la infancia en Sender como "el tiempo de la ya imposible salvación".
} 
Anthony Quinn para dar vida al sacerdote, si obedece al star-system, también introduce un elemento inesperado en el argumento. Para justificar el acento del actor, sorprendente en el contexto de un pueblo aragonés, se menciona en algún momento que ha vivido en Méjico. Este detalle extra-fílmico también permite introducir la perspectiva de un imaginario desconocido, como en la secuencia en la que Pepe le pide al párroco que le enseñe el baile de la lluvia de los indios -y de repente se escucha un ruido de tormenta.

No impide, sin embargo, que el maestro cumpla con su función docente. En una de las primeras secuencias de la película (la segunda del largo flash-back que reconstituye la infancia de Pepe), le vemos interrogando a Pepe sobre los deberes que tenía que hacer. Ante la falta de respuesta del niño, suspira y sentencia: "los gatos saben la lección mejor que tú"; precisamente la secuencia anterior mostraba a Pepe soñando en el tejado y jugando ahí con los gatos. El sacerdote parece por lo tanto omnisciente o, al menos, muy conocedor de los hábitos de su alumno.

Un poco después, se repite este poco gusto de Pepe por las lecciones con una secuencia de clase de matemáticas. Primero, el sacerdote le pregunta por el teorema de Pitágoras; Pepe intenta ganar tiempo y desviar la atención: “Pitágoras, sí es eso que viene ahí en el libro". Luego trata de reconstituir el teorema, mimando con gestos las figuras geométricas, pero parece evidente que no tiene idea de lo que habla: "es de un triángulo... del triángulo sí... el cuadrado de un lado... el lado grande... a un lado... un lado es..."; tampoco logra recitar el teorema de Tales. Sin embargo, el docente no se enfada en absoluto sino que reacciona con cierto de sentido de humor. En este momento, la cámara hace un travelling de retroceso que permite pasar del clásico montaje de oposición (en campo sobre el maestro/contracampo sobre el alumno) a un encuadre de los dos. Mosén Joaquín se acerca a la pizarra y le anuncia una pregunta muy fácil: dibuja un triángulo y le pregunta cuántos ángulos tiene, a lo cual Pepe le contesta que dos. El sacerdote entonces se inclina y se le acerca y sentencia con una mezcla de cansancio y de afecto: “Pepe, la verdad es que tú no sabes nada, pero yo sí sé una cosa de seguro: tú eres un bandido, pero vas a aprender a la fuerza, de esto estoy seguro." Finalmente vuelve a la pizarra y escribe la cifra 30. Cuando Pepe acierta con una sonrisa al leer el número, mosén Joaquín le sonríe 
también para decirle: "ah, ves estás aprendiendo, exactamente: esos son los 30 palos que te va a dar tu padre".

No es el maestro pues, sino el padre, el único encargado de administrar el castigo corporal al niño. La figura del maestro queda por lo tanto exenta del rencor infantil, al contrario de la del padre que parece en muchas ocasiones brutal e incluso inculta. Al descubrir los versos de Bécquer copiados por Pepe, el padre refunfuña: “¡Dios santo! Encima, poeta", como si lo creyera autor de aquéllos3; no lo cree cuando Pepe anuncia que va a haber un eclipse de sol, so pretexto de que no lo ha leído en el periódico; y está convencido de que su hijo sufre trastornos psicológicos por haberle visto "bailando en el tejado", sin sospechar que está comunicando en alfabeto morse con su amada Valentina que lo observa desde su ventana. Hasta vemos a Pepe cogiendo una escopeta escondida por encima de su cama cuando espera a que su padre le castigue, y si bien finalmente no hará uso de ella, deja percibir la fuerte oposición que, por cierto, también anuncia un conflicto que es más el de las dos Españas que el de dos generaciones. De hecho, cuando finalmente vemos a Pepe capaz de recitar los teoremas, es después de recibir el consuelo de su madre tras los golpes de su padre, y haberle prometido que iba a trabajar. La película deja pues claro que es más el afecto (y la privación de la libertad de ver a su amada) lo que motiva al niño que la perspectiva del castigo.

Este rechazo de los estereotipos es un elemento común a otras películas. Queda evidenciado en La Lengua de las mariposas donde el pequeño Moncho (Manuel Lozano) está atemorizado ante la perspectiva de que le pueda pegar el maestro en su primer día de escuela. En una secuencia tragicómica, el maestro, don Gregorio (Fernando Fernán Gómez) tiene que enfrentarse con un padre que le regala dos capones a cambio de que pegue a su hijo, lo que se niega a hacer, así como rechaza el regalo. Tras observar, maravillado, esta escena, Moncho le cuenta a su hermano mayor su primer día de escuela, resumiéndolo con el aura de prestigio del maestro: "don Gregorio no pega", lo que le sorprende a su hermano, un adolescente, quien probablemente haya conocido el sistema educativo anterior y mucho más represivo.

\footnotetext{
3 El contrapicado sobre el padre leyendo los versos pone de realce de manera irónica el desfase entre su creencia de superioridad y su falta de cultura.
} 
El maestro viene pues acompañado en muchas películas de un aura progresista. Queda más patente aún en Las largas vacaciones del 36 donde se identifican las ideas políticas del maestro (Paco Rabal), que acude a dar clases particulares a los hijos de las familias burguesas sorprendidas por la guerra civil durante el veraneo, mediante las preguntas de uno los niños : "Maestro, ¿usted es rojo? es que... mi padre dice que...", y su respuesta:

Imagino lo que dice tu padre. Que los rojos son malos. Sí... Que queman las iglesias. Que pillan, roban y asesinan. Pues mira Pedrito: yo también soy rojo. Y ni robo ni asesino. Me dedico simplemente a enseñar geografía, historia, matemáticas, lengua y literatura para desasnar a los niños de este pueblo, y ahora a vosotros.

Tras hacerle leer el "Recuerdo infantil” de Machado4, les dice a sus nuevos alumnos: “Esto es de Antonio Machado. Rojo", y a petición de un chico que se alistará con los republicanos, cita: "Españolito que vienes/ al mundo, te guarde Dios./ Una de las dos Españas/ ha de helarte el corazón", antes de representar en la pizarra el mapa de España dividida entre el gobierno republicano y la zona dominada por los rebeldes. La cita de Machado entra en resonancia con los gritos del recién nacido hermanito de uno de los alumnos, dado que las clases tienen lugar en su casa. En una secuencia posterior, ya en el invierno de 1938, se le ve al maestro con aspecto muy desmejorado y tosiendo. Mientras los niños acaban de repartirse la ganancia de la venta de unos objetos de quincallería, el maestro empieza la clase preguntándoles si tienen algo de comer: "cualquier cosa, lo que os sobre, si es que os sobra algo. Tengo hambre, paso hambre, y estoy enfermo.". El silencio se instala y en contracampo, un traveling lateral muestra las caras también cansadas, enfermizas y hambrientas de los niños. Finalmente, empieza la clase. Esta película muestra pues al maestro en posición de debilidad: el alumnado le es, al principio,

\footnotetext{
${ }^{4}$ Leída también en la primera clase a la que asiste el pequeño Moncho en La lengua de las mariposas, de modo que la doble intertextualidad -cita directa de Machado y alusión a la película de Jaime Camino- permite sugerir la ideología del maestro, tanto más cuanto que, cuando su madre le pregunta a Moncho: "¿Habéis rezado?", él le contesta: "sí, una cosa de Caín y Abel”, refiriéndose al poema, lo cual deja entender que la enseñanza de don Gregorio es en realidad laica, lo que no sería del gusto de la madre, que concluye: "ya me extrañaba a mí que don Gregorio fuera un ateo".
} 
en parte hostil, por prejuicios ideológicos y de clase y aunque las familias tengan que recurrir a sus servicios. $Y$ posteriormente, si se instaura la compasión, pese a las diferencias ideológicas, lo ven en posición de vulnerabilidad, sin más autoridad o prestigio que los que le confiere el saber.

Con la representación del contexto del tardofranquismo, algo parecido pasa en Vivir es fácil con los ojos cerrados (David Trueba, 2013). El profesor de inglés, Antonio (Javier Cámara) viene presentado de manera poco halagadora. Cuando coge a una chica en autostop (Belén, interpretada por Natalia de Molina) y le propone que adivine cómo los alumnos lo apodan, ella enumera una serie de apodos que remiten a sus defectos físicos: “¿el calvo? ¿el gordito? ¿el cuatro ojos?5”. Tampoco parece partidario de hacer uso de la autoridad: cuando echa de su coche a Juanjo (Francesc Colomer), otro chico que hacía dedo, por declarar que prefiere los Rolling Stones a los Beatles, en realidad está fingiendo y riéndose de su credulidad y del estereotipo de profesor severo al que imita. Finalmente, también se presenta como una figura marginada, incomprendida y solitaria; a Belén que se asombra de que no esté casado, le contesta: "Los profesores, de tanto tratar con los niños, al final acabamos por no entender el mundo de los adultos".

En Eres mi héroe es Mateo (Toni Cantó), el cura y profesor de catecismo quien encarna esta figura de pedagogo libre: cansado por la falta de atención de los adolescentes, y tras descubrir un dibujo erótico en el cuaderno de uno de ellos ${ }^{6}$, acaba proponiéndoles "una clase distinta: libre y democrática” hablando de lo que de verdad les interesa "pero con rigor", y escribe la palabra "SEXO" en mayúsculas en la pizarra. Les anima a preguntar lo que quieran y tras un silencio que traduce el estupor de los adolescentes que un minuto antes no dejaban de hablar, todos levantan la mano simultáneamente en un contrapunto cómico. Posteriormente, tras haberle reclamado otra “clase democrática”, los alumnos le preguntan “por qué no se puede ser cura y comunista” y le cuentan lo que les dice su profesor de FEN7: "que no quiere comunistas en el colegio,

\footnotetext{
${ }^{5}$ Sólo en el momento de despedirse le revelará que le llaman "el quinto Beatle" por su admiración por John Lennon.

${ }^{6}$ Ortega, quien ha imitado La Libertad guiando al pueblo de Delacroix poniéndole cara de su profesora de francés a la Libertad y representándose a su lado.

7 Formación del Espíritu Nacional, una asignatura obligatoria durante el franquismo.
} 
que habrá que echarles de España otra vez porque traen la desunión y la guerra”. El profesor cierra entonces la puerta y, tras calificar a su colega de fascista, algo alterado, les propone decirles la verdad y explicarles "lo que es el fascismo, lo que es el socialismo, lo que es la democracia cristiana, lo que es el comunismo, todo." Pero les pide que guarden el secreto sobre el contenido de su clase, por miedo a ser despedido -lo que finalmente ocurrirá.

La única excepción a este cuadro quizás sea la del maestro don Julián (Fernando Guillén) en El florido pensil, que sí hace uso de los castigos físicos. Sin embargo, pese a que sea el transmisor de la pedagogía nacional-católica, la adaptación del libro de Andrés Sopeña Monsalve utiliza un cambio de focalización respecto a la obra literaria adoptando puntualmente otros puntos de vista que el del niño-protagonista y permitiendo de esta manera dar acceso a la interioridad del maestro como en la secuencia en que tiene este intercambio en casa con su mujer:

(don Julián) - Con esta luz me estoy quedando ciego, no veo nada.

(doña Carmen) - Y si pongo una bombilla más potente, luego la armas cuando llega el recibo. Además ... ¡como si no te supieras ya el catecismo a estas alturas!

(don Julián) - Si es que esto no lo entiende ni el que lo escribió.

Esta fugaz secuencia viene a matizar el retrato del maestro: más que el portavoz del régimen dictatorial, se convierte por lo tanto en su sumiso instrumento. Como explica bien su intérprete en una entrevista:

Es un pobre hombre que por definición es apolítico. Es un hombre que vive en une España gris, pobremente. Realmente es un personaje entrañable y al mismo tiempo muy representativo de lo que eran la mayoría de los españoles en la época. Hacían cosas con las que no exactamente no estaban de acuerdo pero sí hacían cosas que no entendían y no sabían por qué. Impartir unas enseñanzas con las cuales no estás de acuerdo o por lo menos no entiendes bien, pues le convierten en un personaje muy alejado del dogmatismo, del fanatismo, que tiene por ejemplo otro personaje de la película, fundamental, el cura don Secundino (Making off). 
En la mayor parte de estas películas, no es casual que los actores elegidos para el papel del maestro sean actores populares que gozan de una imagen simpática en el imaginario de los espectadores, o incluso que hayan demostrado cierto compromiso político (como Fernando Fernán Gómez o Paco Rabal).

Esta imagen del docente como de una figura exótica, marginada o de perdedor incluso, no impide, sin embargo, que se establezca con los niños protagonistas una relación que es más de amistad que de superioridad o autoridad. Quizás sea precisamente por un juego de identificación, estando el niño, por su edad, condenado al silencio por el mundo de los adultos y más aún en el régimen dictatorial.

\section{Un amigo más que un maestro}

En la secuencia que anteriormente comentamos, Mosén Joaquín se lamenta ante la falta de trabajo de Pepe: se levanta, suspira, tira su boina al suelo y le dice: "yo siempre te he tratado como amigo $8 "$. Finalmente y después de parecer vacilar, hace un gesto resignado antes des escribir la "apreciación global” que aparece mediante un primer plano de detalle "20P": veinte palos. Si la actitud del sacerdote puede aparecer en un primer momento como un intento de chantaje afectivo para animar al niño a estudiar, la continuación de la película mostrará que compagina su afecto por el niño con su preocupación pedagógica. Así por ejemplo, suprime una clase para sustituirla por la observación de un eclipse de sol. Después de conseguir que Pepe aprendiera los teoremas de Tales y Pitágoras, una secuencia episódica le muestra ejerciendo la docencia al aire libre: el juego de canicas es el pretexto para que Pepe recite sus conocimientos sobre el rayo y el diámetro; el plano entero muestra al sacerdote casi tumbado en el suelo, sugiriendo que está tan absorbido por el juego como Pepe.

\footnotetext{
${ }^{8}$ Este aspecto de la relación alumno-docente está muy presente en SENDER (p. 36, 91, 94).
} 


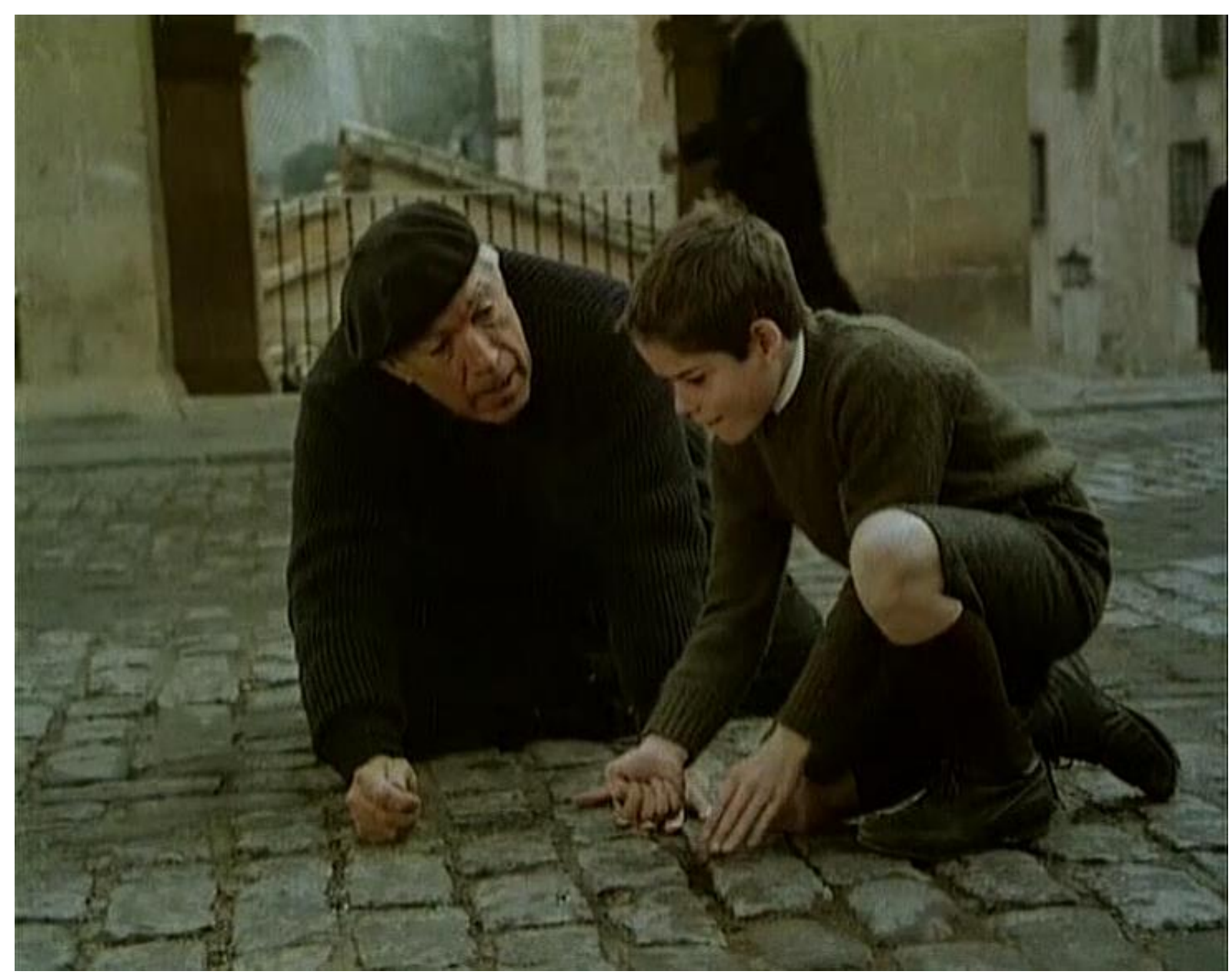

Maestro y alumno al mismo nivel (Valentina).

A continuación, se ve a alumno y maestro corriendo y jugando a perseguirse, pescando -y es Pepe quien ayuda a Mosén Joaquín, que parece entorpecido, a coger el pescado; y finalmente aparecen buscando huellas de la presencia del mar en las rocas. Esta secuencia concluye con el baile de la lluvia que le enseña el cura a su alumno al crepúsculo.

Del mismo modo, La lengua de las mariposas muestra cómo el maestro aprovecha la primavera para desarrollar clases al aire libre, entre las cuales la que da su título a la película.

Pero la relación entre maestro y alumno va más allá incluso de esta pedagogía lúdica. En La lengua de las mariposas, podemos percibir, igual que en Valentina, el respeto al niño por parte del maestro, y la misma manera de tratarle como a un igual: cuando 
Moncho se asusta y huye de la escuela, mosqueado por las burlas de sus compañeros y del maestro que le llamó "gorrión”, el maestro va a buscarlo en su casa. Ahí le trata de usted y le presenta disculpas. Lo lleva de la mano a la escuela, y le invita a sentarse a su lado, en el entarimado, ofreciéndole de ese modo un lugar de honor donde pueda sentirse protegido de las burlas. Del mismo modo, su pedagogía no descansa en el uso del autoritarismo sino en el ejemplo y la reciprocidad: en otra secuencia, le vemos intentando dar explicaciones en medio de los gritos y juegos de los niños; sus intentos para conseguir el silencio quedan vanos, hasta que deja de hablar y se pone a mirar por la ventana, diciendo: “Está bien, si ustedes no se callan, tendré que callarme yo". Entonces Moncho llama la atención de sus compañeros que se van callando. Otra vez, esta anécdota suscita el asombro de Andrés, el hermano mayor de Moncho, cuando se la cuenta: “¿Y no ha dicho nada?”, le pregunta, a lo cual Moncho contesta: "Sí, que muchas gracias". El mismo padre de Moncho, quien es sastre, tiene que decirle al maestro que le considera como un amigo para ofrecerle un traje, en agradecimiento de cómo salvó al niño de un ataque de asma, sumergiéndole en el agua del río. "Los maestros no ganan lo que tendrían que ganar. Ellos son las luces de la República”, le explica el padre de Moncho a su mujer para justificar su regalo.

En Eres mi héroe, cuando Ramón (Manuel Lozano) le confiesa a Mateo que fue él quien se chivó y reveló que el cura había tildado a otro profesor de fascista -cosa que éste ya sabía-, el adolescente se sorprende de que Mateo no le guarde rencor por ello. Mateo justifica entonces su actitud con una declaración de amistad; le dice: “Tu eres mi amigo, un amigo de verdad; ¿recuerdas lo que decíamos en clase? tu amigo es tu hermano”. Ante el semblante serio de Ramón, añade: "aunque te folle", alusión al chiste que le habían hecho los alumnos al sustituir en la frase escrita en la pizarra la a de "falle" por la o. La alusión consigue hacerle reír a Ramón y alumno y profesor se funden en un abrazo. Incluso Mateo le agradece al chaval que haya provocado su despido del instituto: “no me atrevía”, le dice, sugiriendo que se siente feliz de haber recobrado cierta forma de libertad ${ }^{9}$.

\footnotetext{
9 Si bien hay una diferencia entre los personajes de curas en Valentina y Eres mi héroe y los maestros y profesores que aparecen en otras de las películas que hemos mencionado como La lengua de las mariposas y Vivir es fácil con los ojos cerrados, recordemos que la vía del seminario no forzosamente era consecuencia de una vocación -históricamente incluso fue una vía de supervivencia de los benjamines en las familias cuyas tierras heredaba el hijo mayor. En las secuencias finales de Valentina, Mosén Joaquín aparece refunfuñando contra la sotana que le impide bajar las escaleras rápido, lo que podría ser interpretado como un indicio de
} 
En Valentina, cuando Pepe huye con Valentina y los padres de ambos los buscan por el bosque con la ayuda de Mosén Joaquín, éste le contesta al padre de Valentina que amenaza con matar al niño: "El muchacho es noble, se lo aseguro, lo conozco mejor que su padre". Parece afectado cuando, tras encontrar a los niños, el padre de Pepe le anuncia su castigo: tendrá que ir como internado a un colegio. Esto marca su fracaso como docente pero sobre todo su separación de su alumno. La pregunta que le hace en el momento de despedirse de él bien muestra, sin embargo, que no le guarda al niño ningún rencor por su carácter indomable: “Pues, Pepe, los amigos se dan la mano... pero a mí, ¿me das un abrazo?", a la cual Pepe contesta con una sonrisa y echándose en sus brazos (un gesto que nunca se le ve hacer con su padre) ${ }^{10}$.

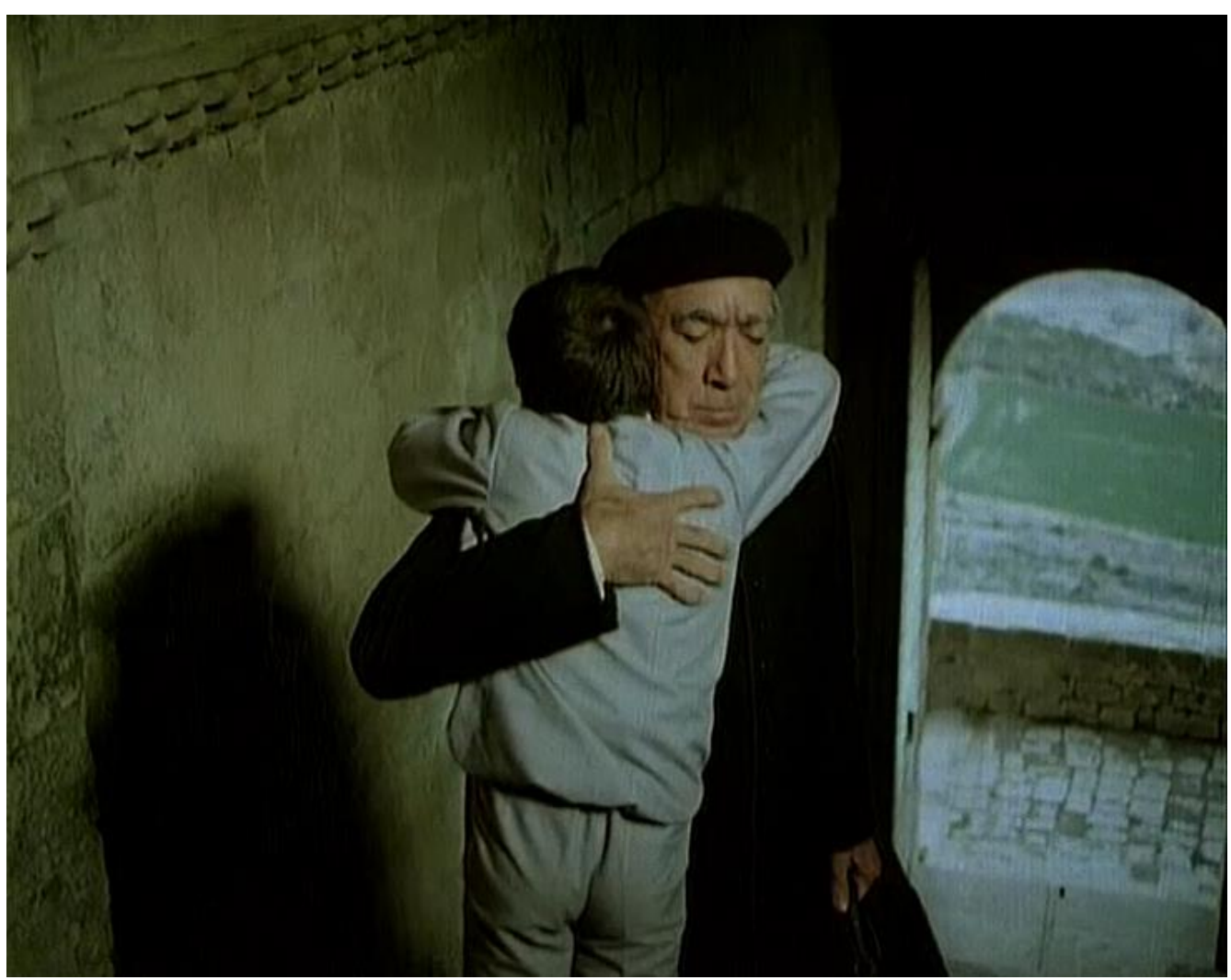

Muestras de afecto (Valentina).

su distanciamiento con una verdadera vocación religiosa. En el libro de Ramón Sender, se sugiere que su vocación es consecuencia de un accidente que le dejó cojo (SENDER, p. 19).

${ }^{10}$ En la obra de Sender, el padre decide enviar a Pepe de interno a un colegio a consecuencia de una pelea en el pueblo, después de la fuga en el castillo, y si en su despedida con Mosén Joaquín, Pepe le pregunta el por qué del destino de los héroes, no menciona que se hayan dado un abrazo (SENDER, p. 137). 


\section{Un iniciador más que un profesor}

Es de notar, por lo tanto, que en la mayoría de las películas estudiadas va construyéndose una relación de amistad y de reciprocidad entre niño y docente. La función pedagógica va elaborándose, por lo tanto, en escasos fragmentos de secuencias de clases tradicionales, más a menudo de forma libre y lúdica. Pero no olvidemos que estas películas sobre la infancia o la adolescencia se construyen como relatos iniciáticos, en los cuales, por lo tanto, es necesaria la figura de un iniciador, a menudo asumida por el docente.

Valentina desarrolla esta faceta del docente como iniciador en toda la película. Tras reprender a Pepe por su comportamiento en la misa, el cura -quien es el único en no tratarle como a un niño diciéndole: "eres joven, casi un hombre”-le pregunta: “¿qué quieres ser tú en la vida?”. En este momento, la cámara enfoca a Pepe sólo mientras contesta: “Nada. Lo que soy.” y mosén Joaquín le pregunta: “¿Y qué eres?”. Ambos aparecen entonces por separado mientras crece la incomprensión del cura ante la respuesta del niño: “yo soy quien soy" y hasta que éste conceda decirle: "Yo soy el señor del amor, del saber y de las dominaciones", repitiendo las palabras que le leyó Valentina durante la misa. Lo más interesante es que a pesar de la cara de asombro que pone el cura, ni se enfada ni se ríe de él, sino que le pregunta: “¡... cuándo supiste todo esto?”. A lo cual Pepe contesta: “Esta mañana” y sigue revelándole que se lo dijo: “Alguien. Alguien para quien soy todo esto. Y me basta".

Cuando el niño admite que fue Valentina, otra vez el cura se muestra no sólo comprensivo sino hábil en su intento de conciliar la vocación amorosa de Pepe con una vocación frente a la sociedad; mientras le da un abrazo, le dice: "Tal vez tiene razón pero tú no lo puedes decir. Uno no puede decir eso de sí mismo, además la gente no te lo va a creer". Finalmente se da por vencido cuando Pepe le contesta: "no me importa que lo crea"; maestro y alumno vuelven a aparecer juntos en el momento de despedirse y citarse para el día siguiente. Es sólo tras la salida de Pepe cuando vemos al cura soltar una carcajada. Precisamente esta secuencia es más significativa de lo que parece. 
A continuación, Pepe aparece en varias ocasiones como un aprendiz de guerrero: cuando se enfrenta con el primo de Valentina y compara su pistola con la escopeta de éste, y acaba disparándose a sí mismo en el dedo para demostrar su supuesta superioridad, lo que le vale que el médico que le quite la bala le califique de "verdadero héroe"”; cuando le enseña su colección de armas y de pólvora a Valentina declarándole "dentro de poco tendré suficiente para volar tu casa y la mía"; cuando presta refuerzo, con su pistola, a un grupo de niños que se enfrentan con los del pueblo vecino pero también con adultos que pretenden poner fin a las batallas con disparos de sal; cuando caza las palomas del padre de Valentina, que representaban para éste un valor económico; y finalmente cuando hace frente a una aparición ${ }^{12}$ en el sótano del castillo familiar, y se ve salvado por la llegada de Valentina y huye con ella ${ }^{13}$.

Esta aparición no es, sin embargo, una mera fantasía sino que tiene su origen en un manuscrito encontrado en el castillo familiar, traducido del latín y leído por mosén Joaquín en una cena familiar:

\begin{abstract}
De tres clases de hombres está hecha la fortuna y la gloria de esta tierra y en general de todas las tierras habitadas por gentes no bárbaras ni salvajes: santos, poetas y héroes.

Los santos, por su corazón amoroso de Dios y de los hombres, han llegado a borrar de su alma las pasiones y los malos afectos y viven en la sombra de las virtudes.

Los otros llegaron, por mucho estudio y servicio contra moros y malos cristianos y porque Dios se sirvió distinguirles con ese privilegio, llegaron a penetrar más que los comunes ojos en las entrañas de las cosas. [...]

Los terceros más necesitados para fundar nuestra grandeza son aquéllos que buscan esforzados hechos y hierro enemigo para escribir con su sangre la cifra de su escudo. Éstos son los héroes.
\end{abstract}

\footnotetext{
${ }^{11}$ Otra vez se insiste en el aspecto sacrificial del protagonista: a Valentina que le pregunta si le duele mucho, él contesta: "sí, pero no importa porque es por ti". Al médico que le pregunta si es valiente, le contesta que sí, antes de que se le oiga gritando desde la sala de espera donde está su padre, convencido de que sufre trastornos psicológicos.

${ }^{12}$ Se distinguen tres siluetas superpuestas: una en armadura, otra encapuchada y la tercera con jubón y lechuguilla, que se presentan a sí mismas como "héroes, santos y poetas".

${ }^{13}$ Pepe no encuentra realmente éxito en sus intentos de ser el señor del saber: cuando pretende estar al tanto del eclipse "por saberlo todo", se enfrenta con las burlas de su padre; tampoco sus intentos de jugar a la guerra resultan logrados, en una clara prolepsis de su destino. Únicamente a ojos de Valentina, que lo acompaña y defiende en todas sus travesuras, y lo llama "mi señor", consigue ser el señor del amor, hasta que los separan los adultos.
} 
La labor iniciadora del docente funciona en esta secuencia para su alumno habitual, pero no sólo. Primero, su capacidad como traductor del latín suple las carencias del padre: “Esto he entendido yo, pero después, claro, mi latín está bastante abandonado”, tiene que reconocer éste cuando el cura empieza a leer su traducción. Pero lo más interesante es que la lectura del preceptor cumple con una función iniciadora y a la vez, conciliadora, entre padre e hijo. El padre manifiesta su interés al escuchar la definición que propone el manuscrito de los poetas: hasta interrumpe al sacerdote para preguntarle: “Los poetas, ¿no es cierto?”. Un plano medio corto muestra a Pepe escuchando fascinado la lectura, y en cuanto termina, se gira hacia su padre y sucede el siguiente diálogo:

(Pepe)-¿Nosotros somos descendientes de los hombres del castillo, papá? (El padre)-Sí. Creo que sí. Desde luego.

(Pepe)-Entonces, ¿qué somos nosotros? ¿Tú eres un héroe?

(Mosén Joaquín)-iEl padre siempre es un héroe!

(La madre)-O un santo.

(Mosén Joaquín)-Ah, no, eso es demasiado, eh.

(El padre)-Y Pepe, aunque no lo parezca, nos ha salido poeta.

(Mosén Joaquín)-¿Ah, sí, poeta?

Por lo tanto la traducción del manuscrito leída por el cura cumple con una doble función: por primera vez, el padre se muestra orgulloso de la vocación literaria de su hijo, porque la ve reconocida y alabada en un texto que goza de cierto prestigio y autoridad. Por otro lado, el niño por primera vez reivindica la herencia paterna en la medida en que le permita inscribirse en un linaje de supuestos héroes. Por último, podemos destacar el hecho de que el sacerdote no toma al pie de la letra la declaración del padre (que de cierto modo también diferencia a su hijo de sí al asignarle el papel de poeta), dado que le pide a Pepe que elija su vocación:

(Pepe)-¿Me deja la traducción hasta mañana?

(Mosén Joaquín)-Te la regalo. Con una condición: tienes que escoger qué vas a ser, héroe, santo o poeta ${ }^{14}$.

\footnotetext{
${ }^{14}$ Nótese que el texto original concluye afirmando que "No puede haber verdadero poeta sin toque de heroísmo, ni verdadero santo sin toque de poeta, ni ninguno en fin de los tres, sin alguna de las virtudes de los otros" (SENDER, p.115).
} 


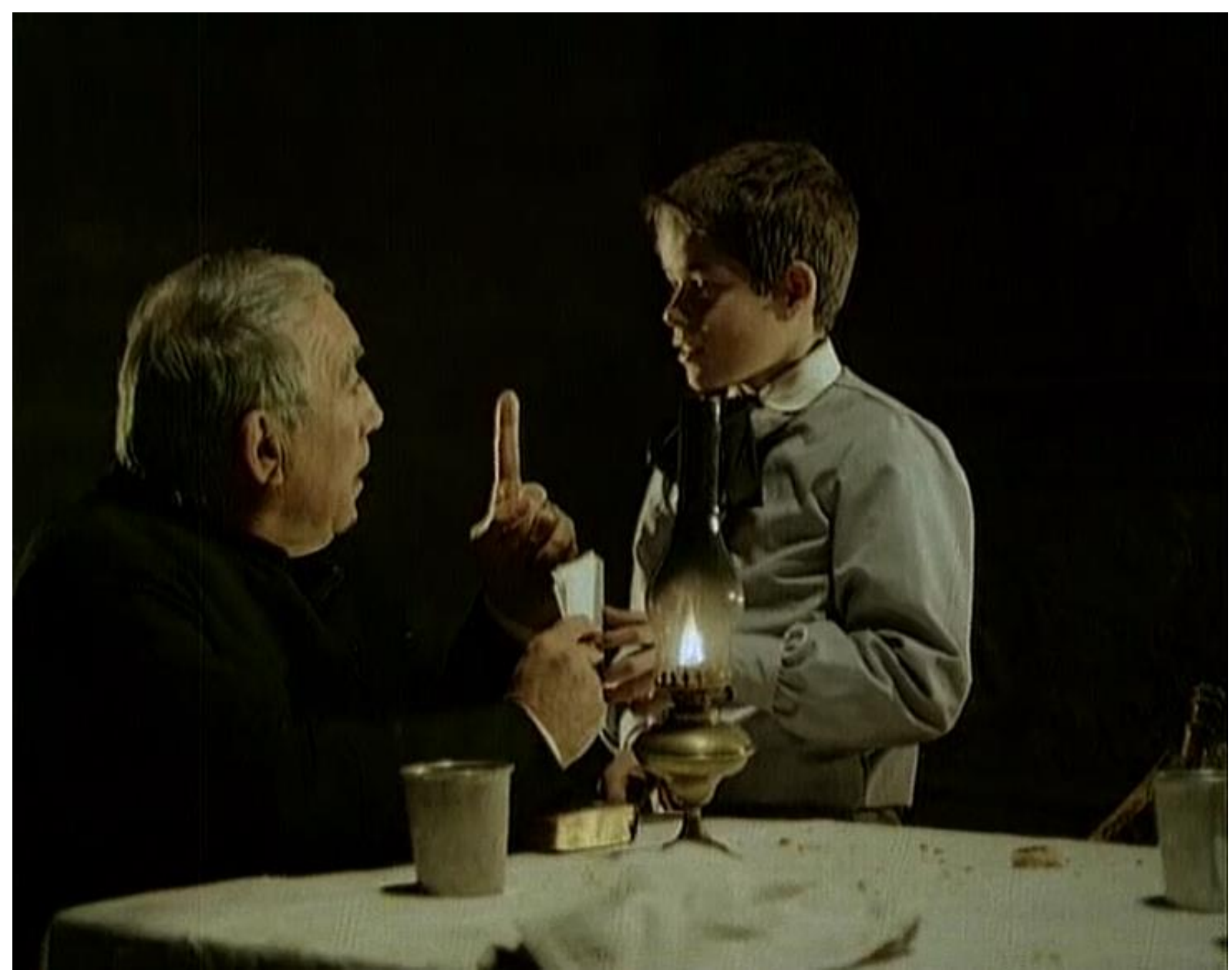

La figura que invita a elegir un camino (Valentina)

El texto y la pregunta del sacerdote le causan pues una fuerte impresión a Pepe dado que al día siguiente (y tras hablar con un viejo pastor que le ha dicho que el sótano está habitado por lamias), se imaginará perseguido en las galerías subterráneas del castillo por fantasmas de héroes, santos y poetas. En el momento de despedirse de su preceptor para irse a un internado después del verano, tienen un intercambio que también deja presagiar su futuro de republicano derrotado:

(Pepe)-¿Por qué matan a los héroes?

(Mosén Joaquín)-iQué pregunta tan difícil! Desgraciadamente cuando seas hombre lo vas a entender. 
En Vivir es fácil con los ojos cerrados, aunque Antonio no sea el profesor de Belén y Juanjo, sino un profesor que les ha ofrecido compartir su coche, también cumple con una función iniciadora, y en este caso, podríamos afirmar que el aprendizaje se lo dirige tanto a sí mismo como a sus jóvenes compañeros de viaje. Poco antes de despedirse para que cada uno vuelva a su casa, Antonio para el coche para enfrentarse con un campesino que agredió a Juanjo por llevar el pelo largo, y ante el susto de los jóvenes, les dice: "Os voy a decir una cosa a los dos. Bien importante: no se puede vivir con miedo. En este país hay mucha gente que vive con miedo. Pero vosotros sois jóvenes, y tenéis que cambiar esto.

Hay que sacudirse el miedo." Pese a que en este momento, se deje empujar dos veces por el campesino sin reaccionar ni obtener que les haga disculpas, posteriormente volverá solo al campo y lanzará su coche en las plantaciones del campesino bajo sus maldiciones, antes de gritar a toda fuerza el título de los Beatles que intentó hacer entender a sus alumnos en la primera secuencia de clase: “Help”. Aquí también existe un relevo de esta función iniciadora, otra vez una figura más mítica que real: la de John Lennon, cuyo mensaje reside en la canción inédita que Antonio grabó en su magnetófono cuando consiguió entrevistarle, y que le deja a Juanjo: "Strawberry Fields Forever", homenaje a su infancia en Liverpool.

En Eres mi héroe, también desempeña este papel de iniciador el cura y profesor Mateo. En la clase que ya hemos mencionado que se convierte en una clase de política, les dirige a los alumnos unas palabras muy enfáticas:

Chavales: ha llegado el momento de luchar. Es una pelea pacífica pero es una pelea, al fin y al cabo. Nadie la puede parar. Ni el propio rey, si quiere reinar. Porque es una pelea que es la pelea de todos y es una pelea que ya está en la calle. Tú me dices, Miguel: "¿se puede ser cura y comunista? ¿se puede ser cura y luchar por la justicia?" No solamente se puede: se debe. ¿Y para qué peleamos? Pues mirad, peleamos para que nuestros compañeros que están en la cárcel solamente por defender unas ideas puedan volver a casa. Y luchamos para que los chavales como vosotros en estos colegios dejen de tragarse tantas mentiras. Hay que luchar. Tenemos que luchar por lo que han luchado tantos y tantos en Europa durante este siglo, tenemos que luchar por una Constitución y por unas elecciones libres. Tenemos que luchar para que el resto de países del mundo dejen de darnos la espalda, para que la igualdad, la libertad y la dignidad se instalen de una puñetera vez en esta tierra. 


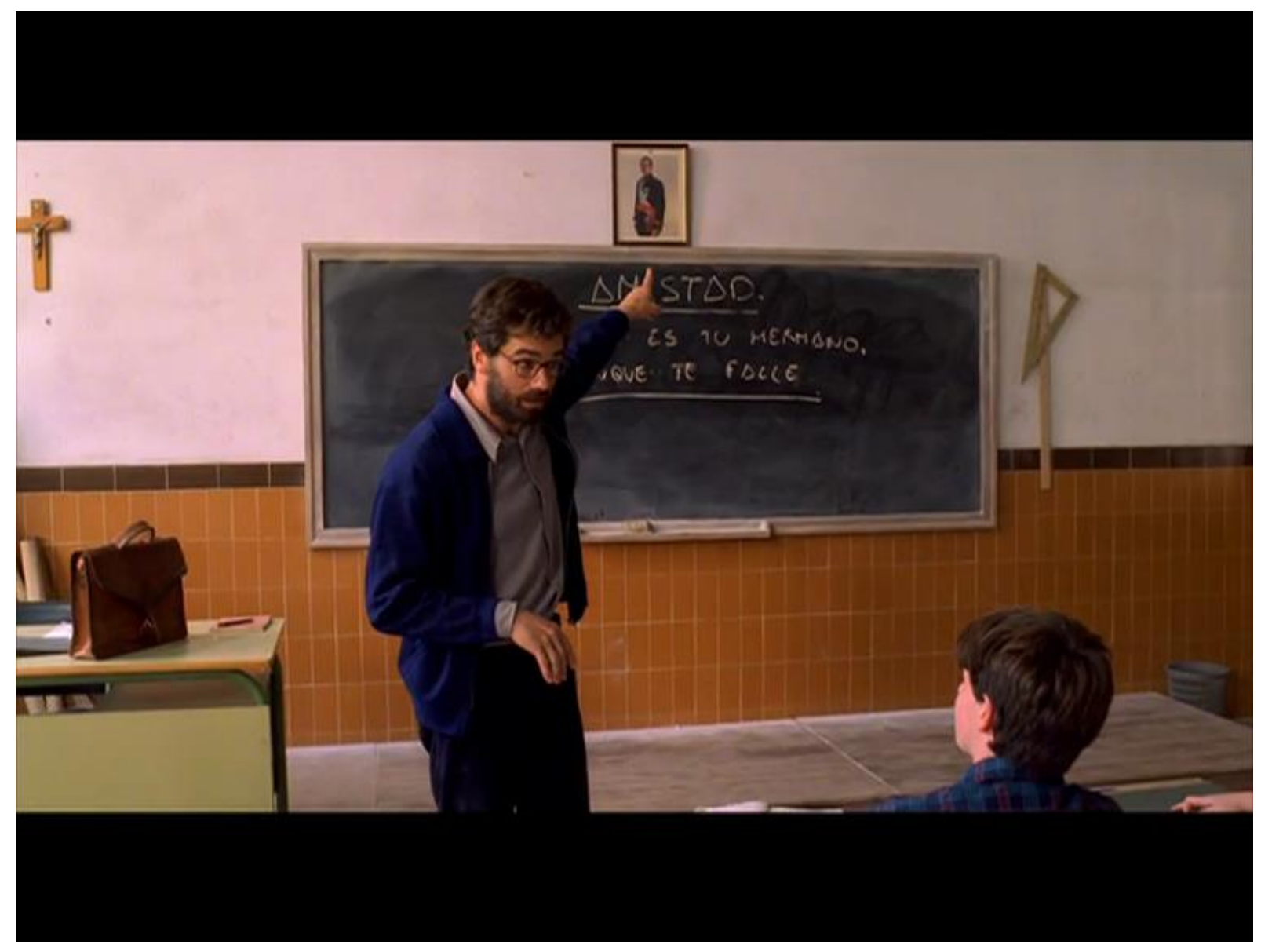

Una iniciación recíproca (Eres mi héroe).

A continuación, el efecto de sus palabras sobre los chavales callados viene sugerido mediante el montaje paralelo, sin palabras y con música, que muestra por un lado, al profesor escribiendo varia series de palabras hasta llenar la pizarra: "FASCISMO. Dictadura fascista”, "TOTALITARIA, REPRESORA, DEMOCRACIA, Poder del Pueblo”, “Xunta Galicia, Euskadi”, “PLATAJUNTA, Blas Infante, PSP”, “Estat català”, “Monarquía, Estado federal, República”, “Sindicato”, “C.C.O.O., UGT”, y por otro lado, a Ramón saliendo de clase con aire decidido, andando y luego corriendo (en la calle pasa delante de unos grafitis que reclaman "poder popular", "Todos por la democracia. JJCC") hasta su casa y su habitación donde saca, del fondo de la caja de un juego, unas octavillas coleccionadas en todas las ciudades y regiones donde ha vivido por las mudanzas debidas al trabajo de su padre: Sevilla, Burgos, Bilbao, Galicia. El profesor es quien parece haberles dado sentido, y tendrá como consecuencia que Ramón, desafiado por sus amigos, pinche una rueda del coche del profesor de FEN. 
Al final de la secuencia, Ramón saca una figurita de indio, "Nube de agua" y la observa, ensimismado. Esta misma figurita funciona como un relevo imaginario del profesor, dado que Ramón la ve apareciendo a su lado en sus momentos de desaliento para darle valor y animarle.

En El espinazo del diablo, también se repite este binomio entre un iniciador real y otro soñado. En la única y fugaz secuencia de clase que se muestra, una clase de historia, la directora del orfanato, Carmen (Marisa Paredes), enseña a los alumnos una ilustración de caza al mamut, que les servirá para fabricarse lanzas y enfrentarse con Jacinto (Eduardo Noriega), el administrador deseoso de hacerse con el oro republicano escondido por Carmen. Las explicaciones de la profesora son una verdadera lección de lucha: "los hombres de entonces tenían que actuar en grupos. Ninguno podía rendirse”. Y cuando los niños están encerrados por Jacinto y tras el incendio en que mueren todos los adultos, de manera inexplicable es el doctor Casares (Federico Luppi), quien les abre la puerta, según Gálvez, uno de ellos que todavía no sabe que ha muerto: “El doctor Casares abrió la puerta. Dijo que me pondría bien. Y que fuéramos valientes". La silueta del doctor apareció, rodeada de moscas, cerca de él, y el joven Carlos (Fernando Tielve) encuentra su pañuelo en el suelo.

En todos estos aspectos, se destaca por lo tanto la repetición de un mismo esquema en la relación alumno-docente en las películas citadas. No podemos, sin embargo, cerrar este estudio sin interrogarnos por la falta de películas que presenten esquemas equivalentes protagonizados en femenino.

\section{La educación femenina, una gran ausente}

No faltan películas, e incluso películas que han tenido gran éxito de crítica y de público, que ponen en escenas a niñas durante el mismo período relacionado con la guerra civil y la dictadura: podemos citar, por ejemplo, El espíritu de la colmena (Víctor Erice, 1973), Cría cuervos (Carlos Saura, 1975), o Alas de mariposa (Juanma Bajo Ulloa, 1991). Escribe Amanda Castro respecto a Cría cuervos: 


\begin{abstract}
El tema central, la infancia y su relación con el mundo familiar, se repetirá en muchos títulos del cine metafórico. La familia era el lugar sagrado por excelencia impuesto por el régimen franquista durante los largos años de dictadura y en él cada miembro tenía un papel perfectamente asignado del que no podía desviarse. La mujer no tenía cabida fuera de este microcosmos, o más bien su existencia carecía de sentido fuera de él, puesto que sus funciones se limitaban única y exclusivamente al interior del hogar. Llama la atención que se elija la mirada de una niña, y no de un niño, para mostrar ese viaje iniciático, esa búsqueda de respuestas a las preguntas fundamentales de la existencia y del posicionamiento en el orden simbólico dentro de unas estructuras familiares férreamente construidas bajo la educación católica y la represión que encerraba. Es una futura mujer la que se pregunta cómo posicionarse dentro de este orden y se rebela ante él, aunque su único camino posible sea la huida hacia el interior. (CASTRO GARCÍA, p. 116)
\end{abstract}

Sin embargo, ninguna de las películas del "cine metafórico" aquí mencionado pone en escena la relación alumna-maestra: la maestra es una figura secundaria en El espíritu de la colmena, donde la figura iniciadora es más bien la hermana mayor; la acción de Cría cuervos se desarrolla durante un período de vacaciones escolares, si bien la figura de la tía puede aparecer como educadora represora, igual que la madre en Alas de mariposa. Como ya hemos señalado, tan sólo en el cine de género cobra cierto relieve, pero entonces como anti-modelo ${ }^{15}$, como en La residencia donde además de martirizar a las alumnas del colegio, crea, mediante su educación represiva, un monstruo en la figura de su hijo. El casting tampoco es casual en este caso: al ser Lilli Palmer quien encarna a este personaje, se crea una intertextualidad con su propio papel en Mädchen in Uniform (Géza von Radványi, 1958), que sugiere una lectura homosexual del ambiente del colegio femenino presente también en varias secuencias que flirtean con el destape (BRÉMARD, p. 56-59). En El espinazo del diablo, sí que hay una figura más ambigua, la de la directora del orfanato, Carmen (Marisa Paredes). Pese a sus palabras simpáticas (insiste en que el orfanato no es una prisión), su

\footnotetext{
${ }^{15}$ Evidentemente, el anti-modelo también puede llegar a tener una función iniciadora, como se desprende de este diálogo de Vivir es fácil con los ojos cerrados cuando Antonio cuenta su encuentro con Lennon a sus jóvenes acompañantes:

“(Antonio)-Hemos hablado de cuando era estudiante, casi todos sus profesores eran horribles.

(Juanjo)-Pues ya tenemos algo en común.

(Antonio)- Tener malos profesores no es tan grave. A veces, si tienes talento, un mal profesor te ayuda a decidir por ti mismo, a no aceptarlo todo sin rechistar. Nuestra profesión es así de absurda".
} 
aspecto físico produce en sus primeras apariciones un efecto inquietante -tiene una prótesis de pierna- acorde con el género fantástico de la película; y la visita del orfanato que hace con el recién llegado Carlos (Fernando Tielve), con la insistencia que expresan los primeros planos en su control del llavero, y sus palabras sobre las fugas de unos colegiales, crea un ambiente pesado y sugiere las desapariciones de niños. Poco a poco, sin embargo, el personaje va revelando su fragilidad (a través de su relación con Jacinto, un ex alumno que ha vuelto para trabajar en el orfanato) y su fuerza - llevaba escondido en la pierna ortopédica el oro republicano codiciado por su cruel amante.

Fuera del cine de género que recurre a la docente pues como figura algo inquietante, algún intento de crear una figura de profesora más verosímil sí ha habido en televisión, pero en la contextualización de la joven democracia, como la de la serie escrita y protagonizada por Ana Diosdado, Segunda enseñanza (Pedro Masó, TVE, 1986). Sin embargo, también se caracteriza por ser un personaje en crisis: ha criado sola a su hija, fruto de una relación con un hombre casado que ha tenido que esconder a pesar suyo, ha abandonado su puesto en un instituto público tras el suicidio de un alumno, y se integra con dificultad en un instituto privado que funciona de manera participativa y cooperativa para evitar una venta a la iglesia católica-, hasta finalmente formar una pareja ${ }^{16}$ con su director, Jandro (Juan Diego), justo en el momento en que éste se ve destituido de la gestión del instituto. Aunque no impida la valoración positiva que reciben los profesores de sus alumnos y alumnas ${ }^{17}$, no cabe duda de que a través de estos personajes, la serie propone un reflejo de un momento de transición de la enseñanza secundaria en España ${ }^{18}$ y no se puede comparar con la mirada nostálgica propuesta por la mayor parte de las películas que hemos evocado (BRÉMARD, p. 34-35).

\footnotetext{
${ }^{16}$ Más precisamente "un buen tándem" como dicen ambos.

17 "Los profes son gente fenomenal, gente que quiere ayudar", le dice una alumna a un nuevo alumno en la secuencia final del último capítulo.

${ }^{18}$ Ana Diosdado afirmaba entonces que el título de la serie anhelaba ser un juego de palabras entre la enseñanza secundaria y "esa segunda enseñanza [...] que los educadores, tanto padres como maestros, pueden y deben obtener de su contacto mutuo y, esencialmente, de su trato con las generaciones más jóvenes" (PÉREZ ORNIA). Segunda enseñanza combinaba dicho interés por parte de Ana Diosdado, al interés del gobierno del PSOE por defender la Ley Orgánica de Derecho a la Educación, examinada por el Tribunal Constitucional mientras se gestaba la serie (CASCAJOSA VIRINO).
} 
Es sorprendente que el cine español no haya desarrollado semejante mirada sobre la educación en femenino ${ }^{19}$. En efecto, los escasos ejemplos que podemos percibir de la educación femenina en las películas citadas también dan cuenta de una represión distinta a la sufrida por los niños por añadirse a la marginación de género mencionada por Amanda Castro. En La lengua de las mariposas, aparece sugerida mediante la aparición fugaz de una chica de la que se enamora el hermano de Moncho, antes de que descubra que quien cree ser su padre es en realidad su marido, dejando clara la falta de acceso de las chicas a la educación y su dependencia económica de los hombres. En Valentina, queda patente en el montaje paralelo que pone en el mismo nivel los golpes que recibe Pepe de su padre por no haber hecho los deberes y las trenzas que le hacen a Valentina. El plano metonímico sobre las piernas de la niña -se rasca una con el otro pie- traduce perfectamente su impaciencia y la falta de libertad que supone para ella este momento en que los adultos controlan su apariencia física atándole el pelo ${ }^{20}$. La educación femenina se aparenta a la masculina en su aspecto de restricción a la libertad. Tras la fugaz y metonímica preparación física de Valentina, en su primera aparición, llega corriendo para ver a Pepe y le dice sin aliento: "mi hermana Pilar es una tonta. Por su culpa no he podido venir antes. He tenido que estudiar el piano²." Las niñas tampoco están exentas de castigos físicos, si bien parecen menos violentos: cuando Pepe le pregunta “¿Tu padre te ha pegado alguna vez?”, Valentina le contesta: “Papá no, pero mamá me da cachetes, pero no me duele porque hago así” e hincha las mejillas. A continuación, ella dice: “Qué tonta [... ] Iba a preguntarte si a ti te ha pegado alguna vez tu padre.”; “Mi padre? ¡Qué tontería!” le contesta Pepe

\footnotetext{
${ }^{19}$ El viaje de Carol (Imanol Uribe, 2002), ambientada durante el viaje a España en 1938 de una niña que se ha criado en Nueva York por ser su padre estadounidense, no propone una relación semejante: la única figura de docente que aparece (Rosa María Sardà) fue maestra de la madre de Carol y no le da clases a ésta, ni tampoco desempeña un papel relevante.

${ }^{20}$ Una secuencia que puede parecer inspirarse en otra similar de La prima Angélica (Carlos Saura, 1974) donde un travelling pasa de la habitación en que pegan a Luis a la otra en que le hacen trenzas a Angélica ; sin embargo, su origen es anterior y se encuentra en el relato de Sender, cuando Pepe explica que convocaba mentalmente la imagen de su amada para aguantar los golpes (SENDER, p. 23-24). Otras correspondencias pueden encontrarse entre la película de Saura y la de Betancor, y Saura reivindica explícitamente la herencia del escritor aragonés al que su madre conoció de joven (SAURA, prólogo). Por el estatuto peculiar de la película de Saura, que mezcla la imagen del cuerpo del adulto con los recuerdos de la infancia, no la hemos incluido en este estudio, aunque también representa una interesante reflexión sobre la educación bajo el franquismo.

${ }^{21}$ A continuación, le explica a Pepe que Pilar toca demasiado de prisa y que lo hace adrede para que no la pueda seguir.
} 
mientras hace un discreto gesto de dolor tras sentarse en una escalera. Por lo tanto, aquí la niña parece (al menos por astucia) salvarse del dolor físico de los castigos, mientras que el niño, pese a que intente disimularlo por orgullo, sí que sufre físicamente las consecuencias de su rebeldía. Estas heridas de Pepe serán un motivo recurrente en toda la película, como presagio evidente de su compromiso y sacrificio en la guerra civil.

Valentina también es reprendida por su madre cuando, durante la misa, le lee a Pepe un fragmento de oración, "Voces del alma enamorada que busca a Dios". Otra vez resulta significativo que dicha censura de los adultos se ejerza sobre la expresión del amor entre los dos niños 22 y más precisamente, la desviación que hacen del texto sagrado hacia lo profano. Posteriormente, otro de los momentos en que se percibe el proceso de aprendizaje vivido por la niña es cuando está en casa y toca el piano con su hermana durante la visita de Pepe (que en realidad se ha fugado de casa para evitar otro castigo paterno): ahí podemos comprobar lo que dijo ella del difícil aprendizaje del piano siendo la benjamina. Si en un primer tiempo, la madre de Valentina parece más permisiva que los padres de Pepe -cuando él anuncia su intención de no volver a casa, le contesta "nadie te obliga"-, también pone interdicciones y obstáculos a la relación entre ambos, como a su petición de dormir en la misma habitación.

En Vivir es fácil con los ojos cerrados, pese a que no aparezcan personajes de profesoras, sí que se las menciona y también se percibe su dureza como educadoras: “A un compañero de clase, la profesora le rompió el tímpano de un bofetón", cuenta Juanjo ante el asombro de Antonio, quien contesta: “¿Una profesora? Pensaba que las mujeres eran más sensibles", un estereotipo positivo enseguida contradicho por la joven Belén, quien recuerda los maltratos de las monjas en cuyo colegio se educó. Es cierto que la película propone seguir la trayectoria iniciática del personaje femenino de Belén, una joven embarazada que se escapó de un internado donde se preparaba a dar a luz y abandonar a su hijo, y elige finalmente volver a casa de su madre. Pero esta elección de Belén era anterior a su encuentro con Antonio, si bien se deja suponer que el camino recorrido con

\footnotetext{
22 En la secuencia anterior en que aparecían juntos, el encuentro con su padre que le recordaba que estaba castigado le impedía a Pepe acompañar a Valentina a casa.
} 
el profesor y el hecho de ver su propio empeño en cumplir su sueño -conocer a su ídolo, John Lennon, de rodaje en Almería- la ayuda a asumir su decisión de criar a su hijo.

La única visión positiva que se proponga de una profesora también responde a estereotipos: en Eres mi héroe, pese a que la historia se desarrolle en un colegio con profesorado mixto, el único personaje de docente femenina que tenga algún relieve es el de la profesora de francés (Geraldine Larrosa), una mujer joven y guapa que despierta las fantasías de los alumnos más que su atención o gusto por el idioma de Molière. Al final del curso, ella parece incluso a punto de llorar ante la obstinación de los alumnos en contestarle en español cuando les hace preguntas en francés. Es entonces cuando Ortega, el que más fascinado por la profesora parecía, se levanta y le da las gracias, en un francés casi perfecto, por haberle hecho amar este idioma, revelando de paso su nombre: Brigitte, como la mítica Bardot.

\section{A modo de conclusión: ¿La relación alumno-docente, una fábrica de héroes?}

Este breve estudio de la relación alumno-docente en el cine español que recrea las circunstancias que desembocaron en la guerra civil y la dictadura deja patente la repetición y la persistencia de una serie de esquemas década tras década. La figura del profesor, sea religiosa o laica, se presenta como más bien progresista, a veces por ello marginada, y la relación que establece con el niño es más de amistad y complicidad que de autoridad directa, en un relato de tipo iniciático, en que el docente aparece como el eslabón esencial que permite la creación de un futuro héroe. ¿Complejo de culpa de una sociedad que controló y oprimió durante casi 40 años a sus docentes (véase MORÁN BREÑA)? Podría ser. Sin embargo, no deja de sorprender que este complejo de culpa no haya implicado, hasta el momento presente, algún tipo de resarcimiento de la figura de la profesora. Esta ausencia -o presencia escasa, secundaria y/o reducida a estereotipos-resulta problemática tomando en cuenta otra afirmación de Marc Ferro, que considera el cine como productor de historia -en el caso que nos interesa, sería pues una historia en la que la docente es la gran olvidada: 
El novelista y el cineasta son [...] productores de historia. Su obra permanece en memoria más aún que las de los historiadores o los periodistas porque tiene un valor estético, y hace entrar en juego el principio de placer. (FERRO, 1997, p. 23, traducción nuestra)

Tras más de 40 años de democracia, y con una más que evidente feminización de la profesión docente ${ }^{23}$, queda por consiguiente por construir figuras de heroínas, queda por poner nombre y cara a profesoras cinematográficas que también a su vez participen en la iniciación, el desarrollo y la realización de héroes y heroínas cotidianos. De cierto modo, ésta sería la mejor manera de cumplir con el deseo de Ramón J. Sender al escribir las memorias de infancia que dieron paso a Valentina; así, sin duda, lo entendió Antonio J. Betancor, al dar a su película este nombre femenino, última palabra que pronuncia -e incluso grita- el héroe separado de su amada:

Quedará en el conjunto de la obra como la de una figura encantadora, con su halo espiritual que tiene ahora y que para mí ha tenido siempre. Sin materialidad alguna, casi... Si yo fuera un poeta como Dante el nombre [de Valentina] quedaría en la historia como el de Beatriz. $Y$ tal vez en el futuro si alguien se acuerda de ese libro mío, citará el nombre [de Valentina] como se cita ahora el de Beatriz. Al menos la idea (atrevida y todo) me gusta ${ }^{24}$ (Carta de Ramón J. Sender a Rodolfo Araus Ventura, 14/10/1966, citada por VIVED MAIRAL).

\footnotetext{
${ }^{23}$ Léase al respecto GRANA GIL y MARTín ZUÑIGA. Sobre la feminización de los últimos años: "La mayor parte de los docentes en España son mujeres. Su presencia varía desde el $96,7 \%$ en educación infantil hasta el $41,3 \%$ en las universidades. Según el informe lgualdad en cifras MEFP, publicado con motivo del Día Internacional de la Mujer por el Ministerio de Educación y Formación Profesional, en la última década la presencia femenina en puestos de dirección de centros no universitarios ha aumentado 15 puntos porcentuales hasta alcanzar el 65\%." (“Las mujeres representan...").

${ }^{24}$ La secuencia de la despedida de Pepe que corre tras el coche que lleva a Valentina no aparece en la obra de Sender -al revés dice que ella dejó el castillo sin que pudieran despedirse (SENDER, p. 131) y es por lo tanto una creación de la película de Betancor. Subrayemos el halo mítico que rodea a la figura femenina desde el prólogo de la película en que el compañero de exilio del difunto Pepe viaja a España para entregarle el manuscrito del protagonista a su amada, diciendo: "Siempre quise saber si Valentina realmente existía".
} 


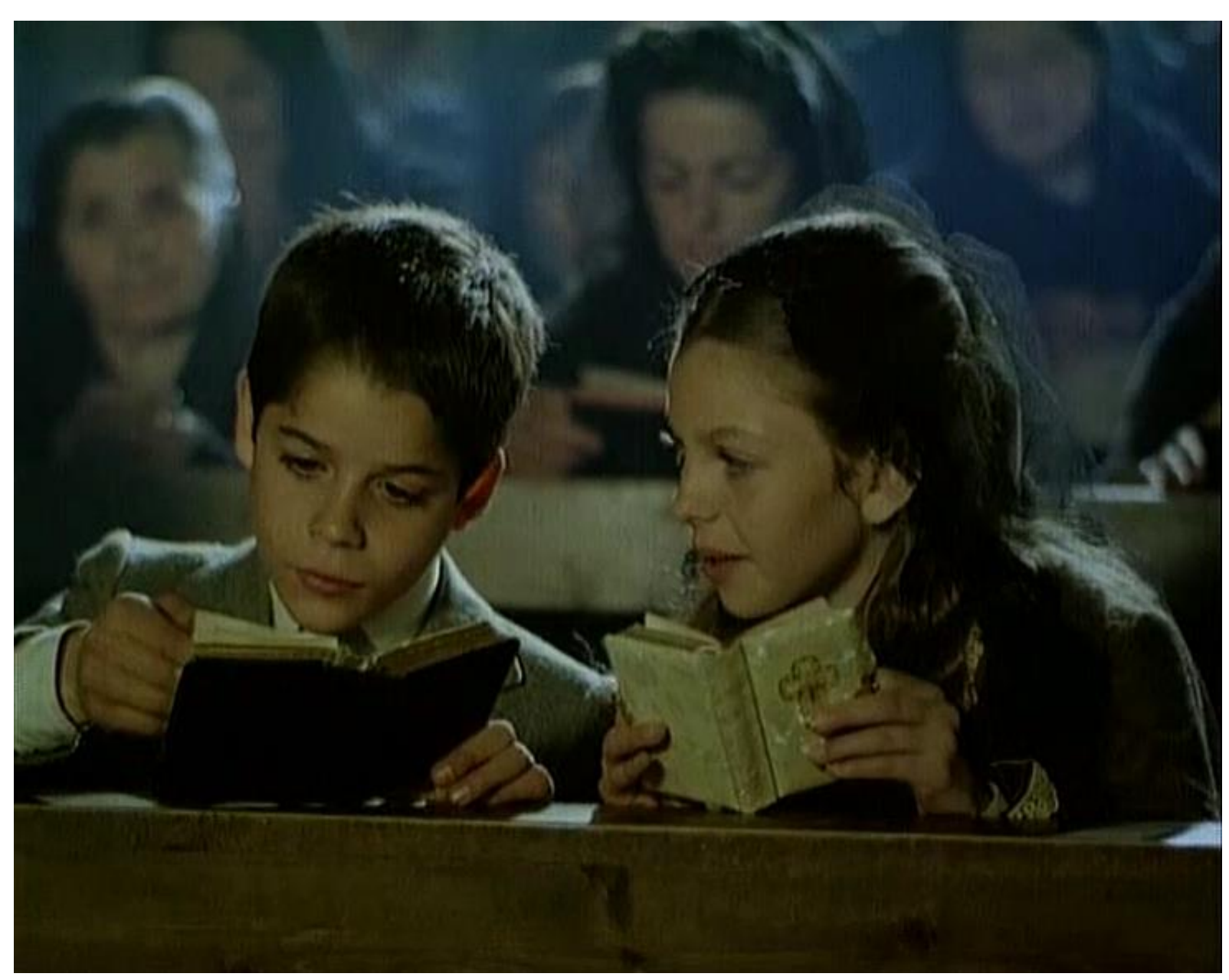

Héroes... y heroínas (Valentina). 


\section{Referencias}

BRÉMARD, Bénédicte. Enfances et adolescences dans le cinéma hispanique. Éditions Universitaires de Dijon: Collection Sociétés, 2016.

CASCAJOSA VIRINO, Concepción. "Un nuevo modelo educativo en la televisión de la transición española: Segunda enseñanza de Ana Diosdado". In Image et éducation, Actes du 7è Congrès international du Grimh. Université Lumière-Lyon 2: Le GRIMH/Passages XXXXI, 2011, p. 239-248.

CASTRO GARCÍA, Amanda. La representación de la mujer en el cine español de la Transición (1973-1982). Oviedo: Ediciones KRK, Colección Alternativas, 2009.

CAUDET, Francisco. Correspondencia Ramón J. Sender-Joaquín Maurín (1952-1973). Madrid: Ediciones de la Torre, 1995.

FERRO, Marc. Cinéma, une vision de l’histoire. Paris: Le Chêne, 2003.

FERRO, Marc. Les Médias et l'histoire. Paris: CFPJ, 1997.

GRANA GIL, Isabel, MARTÍN ZUÑIGA, Francisco. "Las profesoras durante el franquismo: freno a la vanguardia intelectual de las mujeres". Bordón. Revista de pedagogía, Vol. 68, $\mathrm{n}^{\circ} 3,2016$, p. 59-71.

“Las mujeres representan la mayoría del profesorado y de los cargos directivos en la enseñanza no universitaria", http://www.educacionyfp.gob.es/prensa/actualidad/2019/03/20190403aulasigualdad.html, 04/03/2019, última consulta : 12/05/2020.

MORÁN BREÑA, Carmen. "Represión contra los maestros en la Guerra civil”. El País, 27/01/2003, www.elpais.com, última consulta: 18/05/2020.

OTEO SANS, Ramón. "Proyección biográfica de Sender en Ramiro Vallemediano y Pepe Garcés: documentos y testimonios". In ARA TORRALBA, Juan Carlos, GIL ENCABO, Fermín (eds). El lugar de Sender. Actas del I congreso sobre Ramón J. Sender (Huesca 3-7 de abril de 1995), Huesca: Instituto de estudios Altoaragoneses, Zaragoza: Institución Fernando el Católico, 1997, p. 635-647.

PÉREZ ORNIA, José Ramón. "La nueva serie de televisión Segunda enseñanza plantea conflictos generacionales”. El País, Madrid, 23/01/1986, www.elpais.com, última consulta: $12 / 05 / 2020$.

SAURA, Carlos. ¡Esa luz! (Guión cinematográfico). Huesca: Instituto de Estudios Altoaragoneses, 1995. 
SENDER, Ramón J. Crónica del alba I. Madrid: Alianza, 1971 (éd de 1993).

VALLET, François. L'Image de l'enfant au cinéma. Paris: Ed. du Cerf, collection $7^{\mathrm{e}}$ Art, 1991.

VIVED MAIRAL, Jesús. "Tres calas en la biografía de Sender”. In ARA TORRALBA, Juan Carlos, GIL ENCABO, Fermín (eds.). El lugar de Sender, Actas del I Congreso sobre Ramón J. Sender. Huesca: Instituto de Estudios Altoaragoneses, Zaragoza: Institución Fernando el Católico, 1997, p. 121-140.

\section{Filmografía}

Alas de mariposa (Juanma Bajo Ulloa, 1991).

Cría cuervos (Carlos SAURA, 1975).

El espíritu de la colmena (Víctor ERICE, 1973).

El espinazo del diablo Guillermo del TORO, 2001).

El florido pensil (Juan José PORTO, 2002).

Eres mi héroe (Antonio CUADRI, 2002).

La lengua de las mariposas (José Luis CUERDA, 1999).

La residencia (Narciso IBÁÑEZ SERRADOR, 1969).

Valentina (Antonio José BETANCOR, 1982).

Vivir es fácil con los ojos cerrados (David TRUEBA, 2013).

Recebido em: 12/03/2020 Aprovado em: 22/06/2020

Universidade do Estado de Santa Catarina - UDESC Programa de Pós-Graduação em Educação - PPGE Revista Linhas Volume 21 - Número 47 - Ano 2020 revistalinhas@gmail.com 